\title{
The cytotoxicity and insecticidal activity of extracts from Delphinium formosum Boiss. \& Huet
}

\author{
Burcu Sen-Utsukarci' (D), Nurhayat Tabancaㄹ (D), Alden S. Estep ${ }^{3,4}$ (D), Özlem Akbal-Dagistan ${ }^{5}$ (D), \\ Sonja M. Kessler ${ }^{6}$ (1), Zehra Ozturk ${ }^{7}$ (1), James Becnel ${ }^{4}$ (1), Alexandra K. Kiemer ${ }^{6}$ (1), Afife Mat ${ }^{1}$ (i) \\ 'Department of Pharmacognosy, Istanbul University, Faculty of Pharmacy, Istanbul, Turkey \\ ${ }^{2}$ USDA-ARS, Subtropical Horticulture Research Station, Miami, USA \\ ${ }^{3}$ Navy Entomology Center of Excellence, CMAVE Detachment, Gainesville, USA \\ ¿USDA-ARS, Center for Medical, Agricultural, and Veterinary Entomology, USA \\ ${ }^{5}$ Department of Pharmaceutical Technology, Istanbul University, Faculty of Pharmacy, Istanbul, Turkey \\ ${ }^{6}$ Department of Pharmacy, Pharmaceutical Biology, Saarland University, Germany \\ ${ }^{7}$ Republic of Turkey Ministry of Agriculture and Forestry, Ortahisar District Directorate of Agriculture and Forestry, Trabzon, \\ Turkey
}

ORCID IDs of the authors: B.S.U. 0000-0002-2720-9686; N.T. 0000-0003-2802-8796; A.S.E. 0000-0002-8281-3229; 0.A.D. 00000002-6524-3535; S.M.K. 0000-0002-8591-851X; Z.Ö. 0000-0002-7462-6554; J.B. 0000-0003-2464-0005; A.K.K. 0000-00027224-9900; A.M. 0000-0002-9225-8572.

Cite this article as: Sen-Utsukarci B, Tabanca N, Estep AS, Akbal-Dagistan Ö, Kessler SM, Öztürk Z, Becnel J, Kiemer AK, Mat A (2019). The cytotoxicity and Insecticidal activity of extracts from Delphinium formosum Boiss. \& Huet. Istanbul J Pharm 49 (3): 148-153.

\begin{abstract}
Delphinium species are well-known toxic plants with diterpenoid alkaloid contents. There has been no previous investigation on the cytotoxicity of Delphinium formosum. The extracts of the different parts of $D$. formosum, an endemic species in Turkey, were investigated for their cytotoxic activity against the human liver carcinoma cell line (HepG2) and primary human umbilical vein endothelial cells (HUVEC). The cytotoxic effects of twelve extracts and subfractions were determined against HepG2 cells using the MTT assay. The only active extract was applied to the HUVEC as a model for healthy cells. Only one of the alkaloidcontaining extracts from the aerial parts was toxic (IC $50=244,9 \mu \mathrm{g} / \mathrm{mL}$ against HepG2 and $144,4 \mu \mathrm{g} / \mathrm{mL}$ against HUVEC), while the root extracts were inactive. The results were improbable although it is predicted secondary metabolites, such as diterpene alkaloids (methyllycaconitine, browniine, lycoctonine, avardharidine, antranoyllycoctonine, delsemine A/B and lycoctonine). Based on previous studies in the literature, the cytotoxic plants were also expected to exhibit insecticidal activity. Therefore, the cytotoxic extract of $D$. formosum was examined for its adulticidal and larvicidal activity against the yellow fever, dengue fever and the Zika virus vector Aedes aegypti $\mathrm{L}$.
\end{abstract}

Keywords: Delphinium formosum, cytotoxic activity, HepG2, HUVEC, natural insecticidal, Aedes aegypti

\section{INTRODUCTION}

The Delphinium L. genus (Ranunculaceae), with almost 300 species worldwide, consists of 29 species in Turkey (17 endemic to Anatolia). Their usages have a long history of medicinal use. Dioscorides mentioned their use against lice and scorpions. The powders of D. staphisagria L. and D. peregrinum L. were used against lice by the British army in the battle of Waterloo. The dried and mature seeds of D. staphisagria, known as "kokarot, kokarotu, müzüdek, mevezek and mevzek", (Baytop 1999) were used as emetics, purgatives and sedatives (in the treatment of rabies, tetanus, and epilepsy) in traditional Turkish medicine. The usage was left aside due to their high toxicity. Despite their toxicity, their external applications (as ointment, powder form or infusion (1- 
$3 \%)$, to the body or on the head) were observed also, especially for their insect repellent activity. The seeds of D. ajacis $L$ (Syn: Consolida orientalis (Gay) Schröd.) and D. consolida L. (Syn: Consolida regalis S.F. Gray subsp. regalis) are antiparasitic (Ulubelen et al. 2001; Hiller and Melzig 2006).

Vector-borne diseases cause epidemics, leading to serious human health problems. Aedes aegypti (Culicidae), one of these vectors, transmits viruses like Dengue, Yellow fever, Zika, and Chikungunya. According to WHO, yellow fever is an acute viral haemorrhagic disease transmitted by infected mosquitoes, and Dengue is a mosquito-borne viral infection, which causes a flu-like illness, and evolves on occasion into lethal complications. WHO also emphasized that, the symptoms of the infection of Zika virus, transmitted primarily by Aedes mosquitoes, are skin rash, mild fever, muscle and joint pain, headache, conjunctivitis or malaise, and is also a cause of Guillain-Barré syndrome and microcephaly (Masi et al. 2017; WHO February 2018; WHO May 2018; WHO April 2019). Many interventions are conducted to prevent these diseases, and one of them is integrated mosquito control, including the implementation of personal protection, destruction and reduction of its habitats, and insecticidal treatment regimens against adult and larval mosquitoes for the reduction of the virus spread. Reducing the amount of synthetic insecticides or pesticides applied, is preferred because of their undesirable and toxic effects. Frequent chemical interventions can also cause the development of insecticide resistance (Tabanca et al. 2013a; Masi et al. 2016). Therefore, an increasing number of plant-based extracts, essential oils or phytochemicals are being investigated with the aim of determining an effective agent against A. Aegypti (Kamaraj et al. 2010; Pitarokili et al. 2011; Maheswaran and Ignacimuthu 2012; Liu et al. 2012; Kumar et al. 2012; Tabanca et al. 2013a, b; Reegan et al. 2015; Cantrell et al. 2016; Masi et al. 2016; Dias et al. 2017; Carroll et al. 2017; Chantawee and Soonwera 2018; Stappen et al. 2018; Tabanca et al. 2018, 2016a, 2016b).

The alkaloids, one of the most remarkable groups of natural products in these plants, have a wide variety of biological activities. The structures of over a hundred alkaloids have been identified; many of them have elicited an expected anticancer activity (Lu et al. 2012). In addition to the studies on cytotoxic

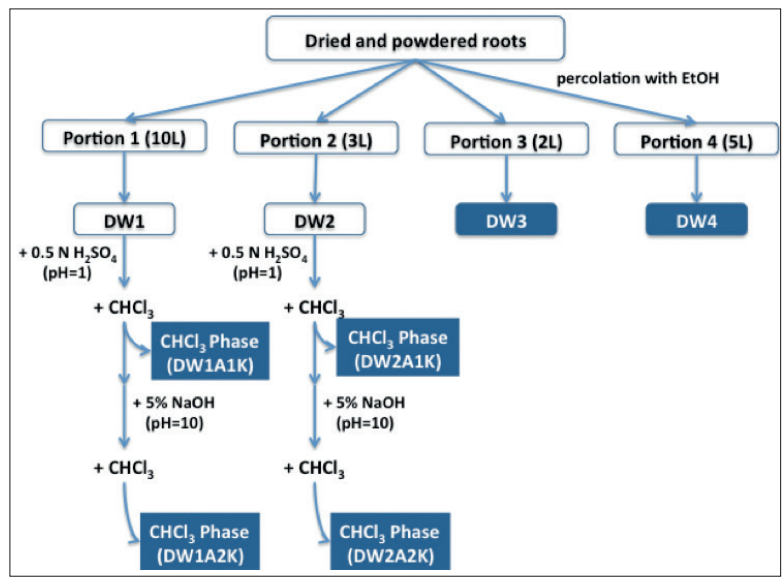

Figure 1. Representative scheme of extraction procedure of the roots, collected in the first year. and anticancer effects (Liu et al. 2017; Nugroho et al. 2015; Chanakul et al. 2011), several investigations into insecticidal activities have been published (Bandara et al. 2000; Garcez et al. 2009; Liu et al. 2012; Masi et al. 2017). The diterpene and norditerpene alkaloids have also shown insecticidal activity (Ulubelen et al. 2001; Kukel and Jennings 1994). Also based on previous studies in literature, the cytotoxicity and insecticidal activities are related to each other, and diterpene alkaloids can be protective agents for parasite control strategies (GonzalezColoma et al. 2004; Reina and Gonzalez-Coloma 2007).

This preliminary study was presented to assess the cytotoxic and insecticidal potentials of extracts, obtained from Delphinium formosum an endemic species in Trabzon (Turkey), which has a role in traditional medicine and causes serious poisoning. The different extracts of its aerial parts, roots, and flowers were investigated for their cytotoxic activity against the human liver carcinoma cell line (HepG2) and primary human umbilical vein endothelial cells (HUVEC). The mosquitocidal activity of the cytotoxic extract against Ae. aegypti was also determined for the possibility to use its lethal potential as an insect repellent.

\section{MATERIALS AND METHODS}

\section{Plant material}

Delphinium formosum was collected from Köprübaşı-Trabzon and Macka-Trabzon, in August 2011 and July 2012. The voucher specimen has been deposited in the Herbarium of the Faculty of Pharmacy, Istanbul University (ISTE 102747; 98086).

\section{Extraction procedure}

Dried and powdered roots, collected in the first year, were percolated with $\mathrm{EtOH}$ in four portions ( $10 \mathrm{~L}, 3 \mathrm{~L}, 2 \mathrm{~L}, 5 \mathrm{~L})$ and each portion was evaporated to dryness at $40^{\circ} \mathrm{C}$ in vacuo (DW1, DW2, DW3 and DW4). The residues of the portions (DW1 and DW2) were acidified to $\mathrm{pH} 1$ by $200-300 \mathrm{~mL} 0.5 \mathrm{~N} \mathrm{H}_{2} \mathrm{SO}_{4}$ and extracted with $\mathrm{CHCl}_{3}$. These $\mathrm{CHCl}_{3}$ extracts were evaporated to dryness (DW1A1K and DW2A1K). The acid solutions were basidified with $5 \% \mathrm{NaOH}$ to $\mathrm{pH} 10$ and extracted a second time with $\mathrm{CHCl}_{3}$. The extracts were evaporated to dryness, and named as DW1A2K and DW2A2K (Figure 1).

Dried and powdered aerial parts, flowers and roots, collected next year, were percolated with $\mathrm{EtOH}$ in one portion and evaporated to dryness at $40^{\circ} \mathrm{C}$ in vacuo. The same process was applied. Two different chloroform extracts of each part (HA1K, HA2K, FA1K, FA2K, 2DWA1K, and 2DWA2K) were acquired (Figure 2).

\section{Biological Assays}

\section{Cytotoxicity Assays}

\section{Cytotoxicity test, cell lines, culture conditions and treat- ments}

Roswell Park Memorial Institute Medium 1640 (without glutamine; RPMI-1640) with glutamine, 10\% FCS and penicillin / streptomycin mixture was used for the human liver carcinoma cells (HepG2). Primary human umbilical vein endothelial cells (HUVEC) were isolated from umbilical cords by digestion with $0.01 \%$ collagenase A solution (Roche) and grown in Endothe- 
lial Cell Growth Medium with a supplement mix (Promocell; C-39215) containing 10\% FCS, penicillin (100 U/mL) / streptomycin $(100 \mathrm{mg} / \mathrm{mL})$ mixture, and kanamycin $(50 \mathrm{mg} / \mathrm{mL})$. Umbilical cords were obtained with the consent of patients (permission by the local ethics committee). All cells were grown at $37^{\circ} \mathrm{C}$ and $5 \% \mathrm{CO}_{2}$ in a humidified cell incubator. The culture medium was changed every 2 days. Monolayer cells grown to $75-85 \%$ confluence were detached with trypsin-ethylenediamine tetraacetic acid to make single cell suspensions, and the viable cells were determined using the trypan blue exclusion test and diluted with medium to give a final density of $10^{5}$ cells $/ \mathrm{mL}$. The passage number range for HepG2 cell lines was maintained between 21 and 26. The passage number for primary HUVEC cells was maintained between 3 and 5. The extracts were initially dissolved in dimethyl sulfoxide (DMSO) and the stock solution of each extract was prepared at a concentration of $20 \mathrm{mg} / \mathrm{mL}$. Next, the stock solutions were diluted in the medium to obtain final concentrations of 10-400 $\mu \mathrm{g} /$ $\mathrm{mL} .100 \mu \mathrm{L}$ of cell suspension per well were seeded into 96well plates at a plating density of $10^{4}$ cells/well for the HepG2 cells and $2 \times 10^{4}$ cells/well for HUVEC, and incubated to allow for cell attachment at $37^{\circ} \mathrm{C}$ and $5 \% \mathrm{CO}_{2}$ for $24 \mathrm{~h}$. After $24 \mathrm{~h}$, the medium was aspirated, and the cells were treated with $100 \mu \mathrm{L}$ serial concentrations of all extracts. The plates were incubated at $37^{\circ} \mathrm{C}$ and $5 \% \mathrm{CO}_{2}$ for $24 \mathrm{~h}$. The medium without samples (negative control) and with DMSO as solvent served as controls. For each extract, all concentrations were tested $n=2$ or $\mathrm{n}=3$ in quadruplicate. The cells in each well were quantified by MTT (3-[4,5-dimethylthiazol-2-yl]-2,5-diphenyl-tetrazolium bromide) test (Kessler et al. 2013; Diesel et al. 2011; Kiemer et al. 2002; Mosmann 1983).

\section{Cytotoxicity studies}

For MTT tests, the cells were then incubated with $150 \mu \mathrm{L}$ MTT ( $0.5 \mathrm{mg} / \mathrm{mL}$ in medium) solution for $3 \mathrm{~h}$. After the removal of the MTT solutions, the formed formazan crystals were solubilized in $80 \mu \mathrm{L}$ of DMSO and then, the absorbance was measured at $550 \mathrm{~nm}$ and at $690 \mathrm{~nm}$ (as control wavelength) using a microplate reader.

The cell viability in treated cells compared to that of negative control cells was calculated. Then, the half maximal inhibitory

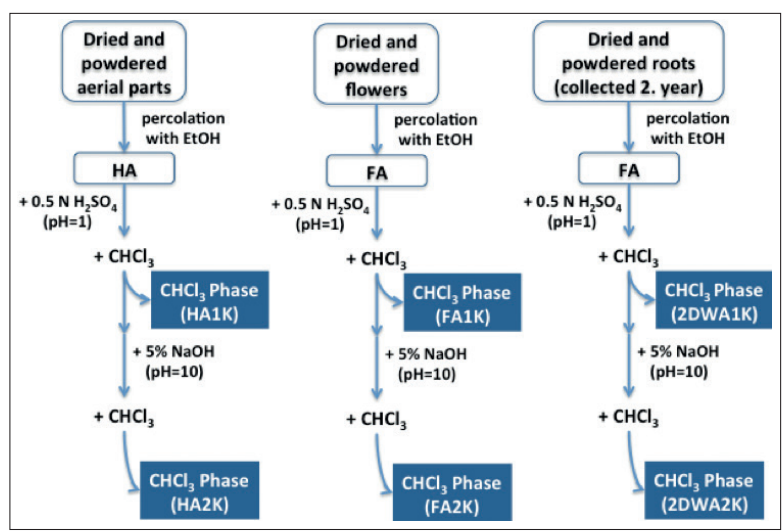

Figure 2. Representative scheme of extraction procedure of the aerial parts and flowers, collected in the first year, and the roots, collected in the second year. concentration $\left(\mathrm{IC}_{50}\right)$ was expressed as the sample concentration that caused an inhibition of 50\% in cytotoxicity in the cells calculated by extrapolation. The percentage of cell viability was calculated with respect to solvent control as follows:

$\%$ Cell viability $=$ Abs compounds $_{\text {Solvent Control }} \times 100$

The results were expressed as cell death (\%) compared to the negative control.

\section{Insecticidal Activity}

\section{Mosquito Colony}

Aedes aegypti used for testing were pesticide susceptible, and provided by the CMAVE insectary. The "Orlando1952"strain was collected near Orlando, Florida, USA in 1952, and has been in continuous laboratory colony for 64 years. Rearing procedures are standardized and have been described previously (Tabanca et al. 2016b).

\section{Larvicidal Activity}

Larvicidal activity testing was performed essentially as described previously (Pridgeon et al. 2008), but the assay was modified for 96-well plates to conserve limited amount of test samples by the use of smaller volumes (Masi et al. 2017). The HA1K extract was diluted in dimethyl sulfoxide (DMSO) to make $100 \mathrm{mg} / \mathrm{mL}$. Mortality was determined in the larval assays at four different concentrations (1.0, 0.5, 0.25, and 0.1 $1 / 4 \mathrm{~g} / 1 / 4 \mathrm{~L}$ ) in a final volume of $2001 / 4 \mathrm{~L}$ of larval rearing media. For each assay, a positive control of permethrin stock and a negative control of ethanol or DMSO was included. Assays were repeated at least three times on separate days using different hatches of eggs.

\section{Adulticidal Activity}

The toxicity of HA1K extract was tested in assays against adult Aedes aegypti using cohorts of 3-6-day post-emergence females as described previously (Pridgeon et al. 2008). Mosquitoes were cold anesthetized on ice, and groups of 10 females sorted into individual plastic cups. An application of $0.5 \mu \mathrm{L}$ of the appropriate dilution of the test chemical was made by repeater pipettor (Hamilton PB600) with a $25 \mu \mathrm{L}$ blunt tip glass syringe (Hamilton 7100 series) to at least twenty females at each dose. Permethrin mixture of $46.1 \%$ cis and 53.2 trans isomers (Chemservice, West Chester, PA) was used as a positive control, and acetone was used as negative control. After treatment, the mosquitoes were kept in plastic cups at $24-26^{\circ} \mathrm{C}$ and $80 \%$ humidity, and supplied with $10 \%$ sucrose in water for $24 \mathrm{~h}$ prior to recording mortality.

\section{RESULT AND DISCUSSION}

Due to the diterpenoid alkaloid content of Delphinium species, we expected distinct cytotoxic actions when testing their effect on HepG2 cells. Only one extract (HA1K) was active among them, in the studied concentration ranges. The same extract was also examined against the HUVEC cells. The $\mathrm{IC}_{50}$ values of HA1K against two cell types $(244.9 \mu \mathrm{g} / \mathrm{mL}$ for HepG2 and $144.4 \mu \mathrm{g} / \mathrm{mL}$ for HUVEC) were similar. 
The MTT assay demonstrated the effect of the extracts on the $\%$ cell viability of HepG2 and HUVEC cell lines as shown in Figure 3 .

The HA1K extract, found cytotoxic against both cell lines, was further investigated for its insecticidal activity (Table 1). The extract was evaluated at the dose of $5 \mathrm{mg} / \mathrm{mosquito}$ and had 97\% mortality against adult Ae. aegypti. The positive control permethrin at $6.33 \mathrm{pg} / \mathrm{mL}$ resulted in $53 \pm 11 \%$ mortality, while the negative control acetone resulted in $0 \%$ mortality. In larval activity, the HA1K extract showed $80 \%$ mortality at the highest dose of $1 \mathrm{mg} / \mathrm{mL}$ against $1^{\text {st }}$ instar Ae. aegypti; however, the mortality tittered off quickly at the lower doses. Negative control mortality in larvicidal assays was $0 \%$ for DMSO, and positive control permethrin resulted in $100 \%$ at the $47.4 \mathrm{pg} / \mathrm{mL}$. Since HA1K extract produced $97 \%$ mortality against adult Ae. aegypti, isolation of the active compound/-s through bioassay-guided fractionation and its/their characterization may be promising.

This is the first investigation on the cytotoxicity and insecticidal activity of $D$. formosum. On the other hand, several studies on the cytotoxic effect of the isolated compounds from other species exist in the literature. De Inés et al. evaluated 43 norditerpenoid alkaloids from Aconitum, Delphinium and Consolida species for their cytotoxic effects on the tumor cell lines SkMel28 (human malignant melanoma), HeLa (human cervical adenocarcinoma), SkMel25 (human melanoma), CT26 (murine colon adenocarcinoma), and SW480 (human colon adenocarcinoma) and the non-tumor cell line $\mathrm{CHO}$ (Chinese hamster ovary cells). Browniine, ajadelphinine, 8-O-methylcolumbianine, dehydrotakaosamine, lycoctonine, 14-deacetylajadine, pubescenine, 14-deacetylpubescenine, 1,14-diacetylcardiopetaline, 18-0-demethylpubescenine, delphatine and neoline showed selective cytotoxicity. The most active compound was a gadesine-type norditerpene alkaloid,

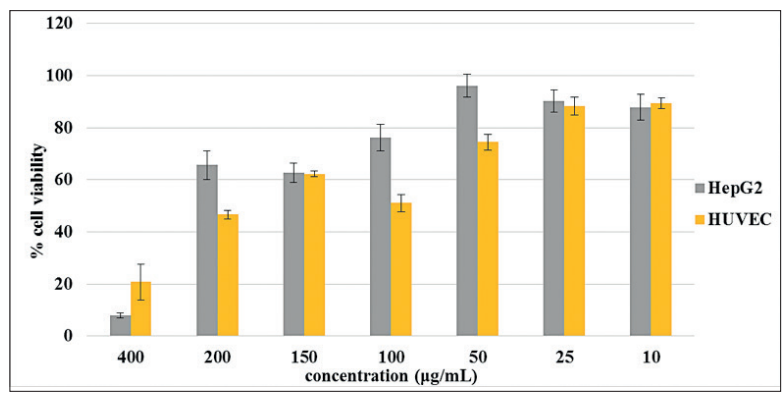

Figure 3. The \% cell viability values of the HA1K against HepG2 and HUVEC cell lines.

\section{Table 1. The mortalities of the HA1K against adult female mosquito $A e$. aegyptiand $1^{\text {st }}$ instar Ae. aegypti larvae}

\begin{tabular}{|c|c|c|c|c|}
\hline $\begin{array}{l}\text { Adult female } \\
\text { mosquito } \\
\text { Aedes aegypti }\end{array}$ & \multicolumn{4}{|c|}{$\begin{array}{c}1^{\text {st }} \text { instar Aedes aegypti } \\
\text { larvae (\% mortality) }\end{array}$} \\
\hline $\begin{array}{l}5 \mu \mathrm{g} / \text { mosquito } \\
\text { [\% mortality] }\end{array}$ & $\begin{array}{c}1 \\
\mu g / \mu L\end{array}$ & $\begin{array}{c}0.5 \\
\mu \mathrm{g} / \mu \mathrm{L}\end{array}$ & $\begin{array}{r}0.25 \\
\mu g / \mu \mathrm{L}\end{array}$ & $\begin{array}{c}0.1 \\
\mu \mathrm{g} / \mu \mathrm{L}\end{array}$ \\
\hline $96.7 \pm 5.8$ & 80 & $53.3 \pm 23.1$ & $13.3 \pm 11.5$ & 0 \\
\hline
\end{tabular}

dehydrotakaosamine. Its $\mathrm{IC}_{50}$ values were detected $0.40 \mu \mathrm{g} / \mathrm{mL}$ against HeLa cells and $6.25 \mu \mathrm{g} / \mathrm{mL}$ against CT26, SW480 and SkMe125 cells. Lycoctonine was found active against CT26 and SW480 $\left(\mathrm{IC}_{50}=50 \mu \mathrm{g} / \mathrm{mL}\right)$, while methyllycaconitine showed an activity against $\mathrm{CHO}, \mathrm{CT} 26$, SW480 and HeLa $\left(\mathrm{IC}_{50}=12.50 \mathrm{\mu g} /\right.$ $\mathrm{mL}, 12.50 \mu \mathrm{g} / \mathrm{mL}, 50 \mu \mathrm{g} / \mathrm{mL}, 50 \mu \mathrm{g} / \mathrm{mL}$; respectively). All $I_{50}$ values of browniine were more than $100 \mu \mathrm{g} / \mathrm{mL}$ against all cell lines, but an effect was seen by browniine against CT26 and SW480 cells (De Ines et al. 2006). In another study, from Aconitum vulparia isolated compounds (vulparine, finetiadine, anthranoyllycoctonine) exhibited a cell growth inhibitory activity against cervix adenocarcinoma (HeLa) and breast adenocarcinoma (MCF-7) cell lines. Finetiadine was the most cytotoxic compound at $30 \mu \mathrm{g} / \mathrm{mL}$ with the $39.48 \pm 3.42 \%$ on MCF-7 cell line and 25.59 $\pm 1.87 \%$ inhibition on HeLa cell line, while septentriodine and anthranoyllycoctonine also showed tumour cell inhibitory activity. Septentriodine showed an activity (34.50 $\pm 3.72 \%$ inhibition) against MCF-7 cells only at the concentration of $30 \mu \mathrm{g} / \mathrm{mL}$ (Csupor et al. 2007).

In a study on Delphinium alkaloids to determine the inhibition of a-bungarotoxin binding to insect and rat neural membranes, 17 Delphinium alkaloids were tested. Among them, glaudelsine showed the highest inhibition on the insect binding site even 10x more potent than methyllycaconitine, which was known as the most potent alkaloid until that date (Kukel and Jennings 1994). In another study, 29 diterpene and norditerpene alkaloids from Delphinium, Consolida and Aconitum species were investigated against Tribolium casteneum (Herbst.) to evaluate the repellent effects. Twenty-one alkaloids exhibited promising insect repellent activity (Ulubelen et al. 2001). Hetisine, a diterpen alkaloid, was found to have the most active repellency (59.12\%). The compounds, delsemin-B, lycoctonine and browniine, showed also an activity against Tribolium casteneum (Ulubelen et al. 2001).

In a previous study from the Black Sea area (Trabzon) in Turkey, $D$. formosum was collected and, delsemine A/B, 14-demethylajacine ( $\mathrm{N}$-acetyldelectine), lycoctonine, anthranoyllycoctonine, delcosine and delectine were identified from the aerial parts (Mericli et al. 1996). Additionally, lycoctonine and delsemine were isolated from D. formosum roots, collected in Trabzon, in a previous study (Tanker and Ozden 1975). Durust et al. (1999) also isolated some phenolic acids such as p-coumaric, p-hydroxy benzoic, caffeic, protocatechic and vanillic acids from the flowers of D. formosum, collected in same region, with four different methods. In our recent study, we reinvestigated norditerpenoid alkaloids from the D. formosum roots, and methyllycaconitine, browniine, lycoctonine, avardharidine, antranoyllycoctonine and delsemine A/B were isolated (SenUtsukarci et al. 2018).

All of the aforementioned studies on the cytotoxic effects of diterpenoids and norditerpenoid alkaloids have a contribution on the cytotoxicity. The difference of the cytotoxicity of D. formosum (aerial parts and roots) can be explained with the diversity of secondary metabolites in the root-extracts. In light of it all, it gives the impression that the extracts may contain different percentages of the active substances. 


\section{Ethics Committee Approval: N/A}

Informed Consent: N/A.

Peer-review: Externally peer-reviewed.

Author Contributions: Concept - B.S.U.; Design - B.S.U.; Supervision - A.M., A.K.K., J.B.; Materials - B.S.U., Z.Ö.; Data Collection and/or Processing - B.S.U., Ö.A.D., N.T., S.M.K.; Analysis and/or Interpretation - B.S.U., N.T., A.S.E., Ö.A.D., S.M.K.; Literature Search - B.S.U.; Writing B.S.U.; Critical Reviews - A.M., A.K.K., J.B.

Acknowledgements: Burcu Sen-Utsukarci thanks the Tincel Vakfi for a fellowship to do a part of this study in Saarbruecken (Germany). All authors thank the Rebuplic of Turkey Governorship of Trabzon (Turkiye Cumhuriyeti Trabzon Valiligi), Republic of Turkey Ministry of Agriculture and Forestry (Turkiye Cumhuriyeti Tarim ve Orman Bakanligi), Trabzon Directorate of Provincial Agriculture and Forestry (Trabzon II Tarim ve Orman Mudurlugu) Tamer Kazaz, Pharm. Oguzhan Baci and Pharm. Çağla Taskiran for the useful support during the work on the land. The authors would like to thank Prof. Dr. Gul Ozhan for useful suggestions.

Conflict of Interest: The authors have no conflict of interest to declare

Financial Disclosure: This work was partly supported by the Research Fund of Istanbul University (Project number: 33641) and partly funded by the Deployed War-Fighter Protection Research Program.

\section{REFERENCES}

- $\quad$ Bandara KA, Kumar V, Jacobsson U, Molleyres LP (2000). Insecticidal piperidine alkaloid from Microcos paniculata stem bark. Phytochem 54: 29-32. [CrossRef]

- Baytop T (1999). Türkiye'de Bitkilerle Tedavi (Geçmişte ve Bugün). Nobel Tip Kitabevleri Ltd, Turkey.

- Cantrell CL, Jones AMP, Ali A (2016). Isolation and Identification of Mosquito (Aedes aegypti) Biting Deterrent Compounds from the Native American Folk Remedy Plant Hierochloë odorata (Sweetgrass). J Agric Food Chem 64: 8352-8358. [CrossRef]

- Carroll JF, Demirci B, Kramer M, Bernier UR, Agramonte NM, Baser KHC, Tabanca N (2017). Repellency of the Origanum onites L. essential oil and constituents to the lone star tick and yellow fever mosquito. Nat Prod Res 31: 2192-2197. [CrossRef]

- Chanakul W, Tuchinda P, Anatachoke N, Pohmakotr M, Piyachaturawat $P$, Jariyawat $S$, Suksen $K$, Jaipetch T, Nuntasaen N, Reutrakul V (2011). Cytotoxic alkaloids from stems, leaves and twigs of Dasymaschalon blumei. Fitoterapia 82: 964-968. [CrossRef]

- Chantawee A, Soonwera M (2018). Efficacies of four plant essential oils as larvicide, pupicide and oviposition deterrent agents against dengue fever mosquito, Aedes aegypti Linn. (Diptera: Culicidae). Asian Pac J Trop Biomed 8: 217-225. [CrossRef]

- Csupor D, Forgo P, Zupko I, Szabo P, Hohmann J (2007). Anthranoyl-substituted Norditerpene Alkaloids from Aconitum vulparia Rchb. and Their Cytotoxic Activities. Z Naturforsch 62b: 135-141. [CrossRef]

- De Ines C, Reina M, Gavin JA, Gonzalez-Coloma A (2006). In vitro Cytotoxicity of Norditerpenoid Alkaloids. Z Naturforsch 61c: 1118. [CrossRef]

- $\quad$ Dias CN, Silva de Mesquita LS, Coutinho DF, Malik S (2017). Plant Derived Essential Oils Against Aedes aegypti L. and Their Biotechnological Production. In: Ghorbanpour M, Varma A (eds.) Medicinal Plants and Environmental Challenges. Springer, Cham. [CrossRef]

- $\quad$ Diesel B, Ripoche N, Risch RT, Tierling S, Walter J, Kiemer AK (2011). Inflammation-induced up-regulation of TLR2 expression in human endothelial cells is independent of differential methylation in the TLR2 promoter CpG island. Innate Immun 18: 112-123. [CrossRef]

- Durust N, Bozan B, Ozden S, Durust Y, Baser KHC (1999). The Quantitative Determination of Some Phenolic Acids in Delphinium formosum by HPLC. Anal Lett 32: 2841-2849. [CrossRef]

- Garcez WS, Garcez FR, de Silva LMGE, Hamerski L (2009). Larvicidal activity against Aedes aegypti of some plants native to the West-Central region of Brazil. Bioresour Technol 100: 6647-6650. [CrossRef]

- Gonzalez-Comola A, Reina M, Guadano A, Martinez-Diaz R, Diaz JG, Garcia-Rodrigez J, Alva A, Grandez M (2004). Antifeedant C20 Diterpene Alkaloids. Chem Biodivers 1: 1327-1335. [CrossRef] Hiller K, Melzig MF (2006). Lexikon der Arzneipflanzen und Drogen. 3th ed, Area Verlag, Germany.

- Kamaraj C, Rahuman AA, Mahapatra A, Bagavan A, Elango G (2010). Insecticidal and larvicidal activities of medicinal plant extracts against mosquitoes. Parasitol Res 107: 1337-1349. [CrossRef]

Kessler SM, Pokorny J, Zimmer V, Laggai S, Lammert F, Bohle RM, Kiemer AK (2013). IGF2 mRNA binding protein p62/IMP2-2 in hepatocellular carcinoma: antiapoptotic action is independent of IGF2/PI3K signaling. Am J Physio/ Gastrointest Liver Physio/ 304: 328-336. [CrossRef]

- $\quad$ Kiemer AK, Weber NC, Fürst R, Bildner N, Kulhanek-Heinze S, Vollmar AM (2002). Inhibition of p38 MAPK Activation via Induction of MKP-1 Atrial Natriuretic Peptide Reduces TNF--Induced Actin Polymerization and Endothelial Permeability. Circ Res 90: 874-881. [CrossRef]

- Kukel CF, Jennings KR (1994). Delphinium alkaloids as inhibitors of a-bungarotoxin binding to rat and insect neural membranes. Can J Physiol Phamacol 72: 104-107. [CrossRef]

- Kumar S, Wahab N, Mishra M, Warikoo R (2012). Evaluation of 15 Local Plant Species as Larvicidal Agents Against an Indian Strain of Dengue Fever Mosquito, Aedes aegypti L. (Diptera: Culicidae). Front Physio/ 3: 1-6. [CrossRef]

- $\quad$ Liu ZL, Liu QZ, Du SS, Deng ZW (2012). Mosquito larvicidal activity of alkaloids and limonoids derived from Evodia rutaecarpa unripe fruits against Aedes albopictus (Diptera: Culicidae). Parasitol Res 111: 991-996. [CrossRef]

- $\quad$ Liu F, Tan X, Han X, Li X, Li N, Kang W (2017). Cytotoxicity of Aconitum alkaloid and its interaction with calf thymus DNA by multispectroscopic techniques. Scientific Reports 7 Article 14509 doi:10.1038/s41598-017-15240-9. [CrossRef]

- Lu J-J, Bao J-L, Chen X-P, Huang M, Wang Y-T (2012). Alkaloids Isolated from Natural Herbs as the Anticancer Agents. Evid.-Based Complementary Altern Med Article ID 485042 doi: http://dx.doi. org/10.1155/2012/485042 [CrossRef]

- Maheswaran R, Ignacimuthu S (2012). A novel herbal formulation against dengue vector mosquitoes Aedes aegypti and Aedes albopictus. Parasitol Res 110: 1801-1813. [CrossRef]

Masi M, van der Westhuyzen AE, Tabanca N, Evidente M, Cimmino A, Green IR, Bernier UR, Bencel JJ, Bloomquist JR, Otterlo, WAL, Evidente A (2017). Sarniensine, a mesembrine-type alkaloid isolated from Nerine sarniensis, an indigenous South African Amaryllidaceae, with larvicidal and adulticidal activities against Aedes aegypti. Fitoterapia 116: 34-38. [CrossRef]

Masi M, Cala A, Tabanca N, Cimmino A, Green IR, Bloomquist JR, van Otterlo WAL, Maacias FA, Evidente A (2016). Alkaloids with Activity against the Zika Virus Vector Aedes aegypti (L.) - Crinsarnine and Sarniensinol, Two New Crinine and Mesembrine Type Alkaloids Isolated from the South African Plant Nerine sarniensis. Molecules 21: 1432. [CrossRef]

- Masi M, Cimmino A, Tabanca N, Becnel JJ, Bloomquist JR, Evidente $A$ (2017). A survey of bacterial, fungal and plant metabolites against Aedes aegypti (Diptera: Culicidae), the vector of yellow and dengue fevers and Zika virus. Open Chem 15: 156-166. [CrossRef] 
- Mericli F, Mericli AH, Becker H, Ulubelen A, Özden S, Dürüst N, Tanker M (1996). Norditerpenoid Alkaloids From Delphinium formosum. Phytochemistry 42: 1249-1251. [CrossRef]

- Mosmann T (1983). Rapid Colorimetric Assay for Cellular Growth and Survival: Application to Proliferation and Cytotoxicity Assays. $\mathrm{J}$ Immunol Methods 65: 55-63. [CrossRef]

- Nugroho AE, Akbar FF, Wiyani A, Sudarsono (2015). Cytotoxic Effect and Constituent Profile of Alkaloid Fractions from Ethanolic Extract of Ficus septica Burm. f. Leaves on T47D Breast Cancer Cells. Asian Pac J Cancer Prev 16: 7337-7342. [CrossRef]

- Pitarokili D, Michaelakis A, Koliopoulos G, Giatropoulos A, Tzakou O (2011). Chemical composition, larvicidal evaluation, and adult repellency of endemic Greek Thymus essential oils against the mosquito vector of West Nile virus. Parasitol Res 109: 425-430. [CrossRef]

- Pridgeon JW, Pereira RM, Becnel JJ, Allan SA, Clark GG, Linthicum KJ (2008). Susceptibility of Aedes aegypti, Culex quinquefasciatus Say, and Anopheles quadrimaculatus Say to 19 Pesticides with Different Modes of Action. J Med Entomol 45: 82-87. [CrossRef]

- Reegan AD, Gandhi MR, Paulraj MG, Ignacimuthu S (2015). Ovicidal and Oviposition Deterrent Activities of Medicinal Plant Extracts Against Aedes aegypti L. and Culex quinquefasciatus Say Mosquitoes (Diptera: Culicidae). Osong Public Health Res Perspect 6: 64-69. [CrossRef]

- Reina M, Gonzalez-Coloma A (2007). Structural diversity and defensive properties of diterpenoid alkaloids. Phytochem Rev 6: 8195. [CrossRef]

- $\quad$ Sen-Utsukarci B, Zapp J, Kiemer AK, Mericli AH (2018). A Reinvestigation of Norditerpenoid Alkaloids from the Roots of Delphinium formosum. Chem Nat Compd 54: 405-406. [CrossRef]

- Stappen I, Tabanca N, Ali A, Wanner J, Lal B, Jaitak V, Wedge DE, Kaul VK, Schmidt E, Jirovetz L (2018). Antifungal and repellent activities of the essential oils from three aromatic herbs from western Himalaya. Open Chem 16: 306-316. [CrossRef]
Tabanca N, Ali Z, Bernier UR, Epsky N, Nalbantsoy A, Khan IA, Ali A (2018). Bioassay-guided isolation and identification of Aedes aegypti larvicidal and biting deterrent compounds from Veratrum lobelianum. Open Chem 16: 324-332. [CrossRef]

Tabanca N, Tsikolia M, Ozek G, Ozek T, Ali A, Bernier UR, Duran A, Baser KHC, Kahn IA (2016a). The Identification of Suberosin from Prangos pabularia Essential Oil and Its Mosquito Activity Against Aedes aegypti. Rec Nat Prod 10: 311-325.

- Tabanca N, Bernier UR, Agramonte NM, Tsikolia M, Bloomquist JR (2016b). Discovery of Repellents from Natural Products. Curr Org Chem 20: 2690-2702. [CrossRef]

Tabanca N, Avonto C, Wang M, Parcher JF, Ali A, Demirci B, Raman V, Khan IA (2013a). Comparative Investigation of Umbellularia californica and Laurus nobilis Leaf Essential Oils and Identification of Constituents Active against Aedes aegypti. J Agric Food Chem 61: 12283-12291. [CrossRef]

- Tabanca N, Benrier UR, Ali A, Wang M, Demirci B, Blythe EK, Khan SI, Baser KHC, Khan IA (2013b). Bioassay-Guided Investigation of Two Monarda Essential Oils as Repellents of Yellow Fever Mosquito Aedes aegypti. J Agric Food Chem 61: 85738580. [CrossRef]

Tanker M, Ozden S (1975). Delphinium formosum Boiss et Huet Bitkisinin Alkaloitleri Yonunden Kimyasal Arastirmalar. J Fac Pharm Ankara 5: 113-139. [CrossRef]

Ulubelen, A., Mericli, A.H., Mericli, F., Kilincer, N., Ferizli, A.G., Emekci, M., Pelletier SW (2001). Insect Repellent Activity of Diterpenoid Alkaloids. Phytother Res 47: 170-171. [CrossRef]

WHO, May 2018, http://www.who.int/news-room/fact-sheets/ detail/yellow-fever

WHO, April 2019, https://www.who.int/news-room/fact-sheets/ detail/dengue-and-severe-dengue

WHO, February 2018, http://www.who.int/news-room/factsheets/detail/zika-virus 